\title{
Csavar implantátum behelyezése az állcsontba az 1930-as években a debreceni Sebészeti Klinikán
}

\author{
DR. KELENTEY BARNA, DR. LUKÁCS LEVENTE, DR. REDL PÁL, DR. HEGEDÜS CSABA
}

\begin{abstract}
Az elmúlt 30-40 évben a fogászati implantátumok alkalmazása jelentősen megváltoztatta a fogpótlások készítésének lehetőségét. Az első bizonyíték az implantátumokra a maja kultúrából ered (i. sz. 600 körül), Európában az 1500-1800-as években többféle módon és különféle anyagok beültetésével próbálkoztak.

Magyarországon elsőként 1934-ben Debrecenben helyeztek be csavar implantátumokat alsó állcsontba, melyekre szinte azonnal hídpótlást készítettek. A mútéteket Hüttl Tivadar sebészprofesszor és Karácsonyi Ágoston fogorvos végezték. Számos esetben alkalmazták az eljárást, melyet szabadalmaztatni is kívántak, de egy budapesti vizsgázott fogász felszólalása miatt 1935. tavaszán a beadványukat visszavonták.

Pontosan nem ismerjük a behelyezett implantátumok számát, a sikerességi rátát, azonban tartósságukat jól mutatja, hogy még 1959-ben is találkoztak olyan beteggel, aki még akkor is használta az így elkészült rögzített fogpótlását. Az esetről fényképekkel és röntgenfelvételekkel kiegészített tudományos közlemény született.

Cikkünk röviden áttekinti az eljárás menetét, eszközeit és a szabadalmaztatással kapcsolatos ellentmondásokat.
\end{abstract}

Kulcsszó: implantátum, csavar implantátum.

\section{Bevezetés}

Az elmúlt 30-40 évben a fogászati implantátumok alkalmazása jelentősen megváltoztatta a fogpótlások készítésének lehetőségeit. Az első próbálkozásokra a régészeti leletek szerint az ősi Egyiptomban és Dél-Amerikában leltek rá $[1,13]$. A következő bizonyíték a fogászati implantátumokra a maja kultúrából ered i. sz. 600-ból, amikor kagylóból készített implantátumot helyeztek alsó metszőfog helyére (körülötte kompakt csontállomány képződött). Kb. 200 évvel később pedig kőből készített implantátumot helyeztek be a mandibulába a korai hondurasi társadalomban.

Európában, az 1500-1800-as években szegényekből eltávolított vagy cadaver-fogakat gyüjtöttek és helyeztek be az állcsontokba. 1647-ben homológ fogreplantációt végeztek, 1685-ben Allen javasolta a human fog transzplantáció helyett pávián-, juh-, kutyafog alkalmazását [21]. Az 1700-as években Hunter transzplantált valódi fogakat egyik emberből a másikba. Fejlődését be nem fejezett fogakkal is kísérletezett. 1809-ben Maggiolo aranytubust ültetett friss extractiós sebbe, sajnos kevés sikerrel. 1863-ban Mitscherlich porcelán, 1906-ban Greenfield arannyal bevont iridium-platina hengeres mügyökeret tett be állkapocscsontba pácienseinél [3, 14]. Az 1930-as években Alvin és Moses Strock ortopéd Vitallium (kobalt-króm) csavarral kísérletezett. Ők tették be az első sikeres enosseális implantátumot is [17]. A későbbiekben egyre többen helyeztek be az állcsontokba implantátumokat, melyek többféle anyagból és formában készültek, és különféle módokon kerültek behelyezésre.

Az implantátumok tartós és erőteljes rögzülése a csontban osseointegrációval történik, amikor a környező csont átépül, és „körülnövi” az idegen anyagot. Az osseointegráció biztos kialakulását számos felületkezelő eljárással próbálták javítani (például savazás, homokfúvás, hidroxiapatit-bevonás, fluoridálás stb.) [1].

Az alábbiakban ismertetett hazai eljárás, melyet egy a Fogorvosi Szemlében 1959-ben Harsághy Nándor tollából megjelent közlemény alapján kezdtünk vizsgálni, már akkor számos hazai és külföldi kolléga érdeklödését keltette fel [7]. Az 1930-as években Debrecenben végzett beavatkozást írt le, mely világviszonylatban is az elsők közé tartozott.

\section{Esetismertetés}

Egy budapesti szakorvosi rendelőintézetben 1959-ben megjelent panaszos, 62 éves nőbeteg alsó állcsontjában ugyanis két rozsdamentes csavar implantátumot találtak a 46-os és a 37-es fogak helyén, melyeket még Hüttl Tivadar professzor és Karácsonyi Ágoston fogorvos helyeztek be a debreceni Sebészeti Klinikán - a beteg elmondása szerint - 1936-ban, azaz 23 évvel korábban. Azok hídpillérként szolgáltak, bal oldalon a másik, valódi pillérfog a 33-as volt, jobb oldalon a 43-as. 

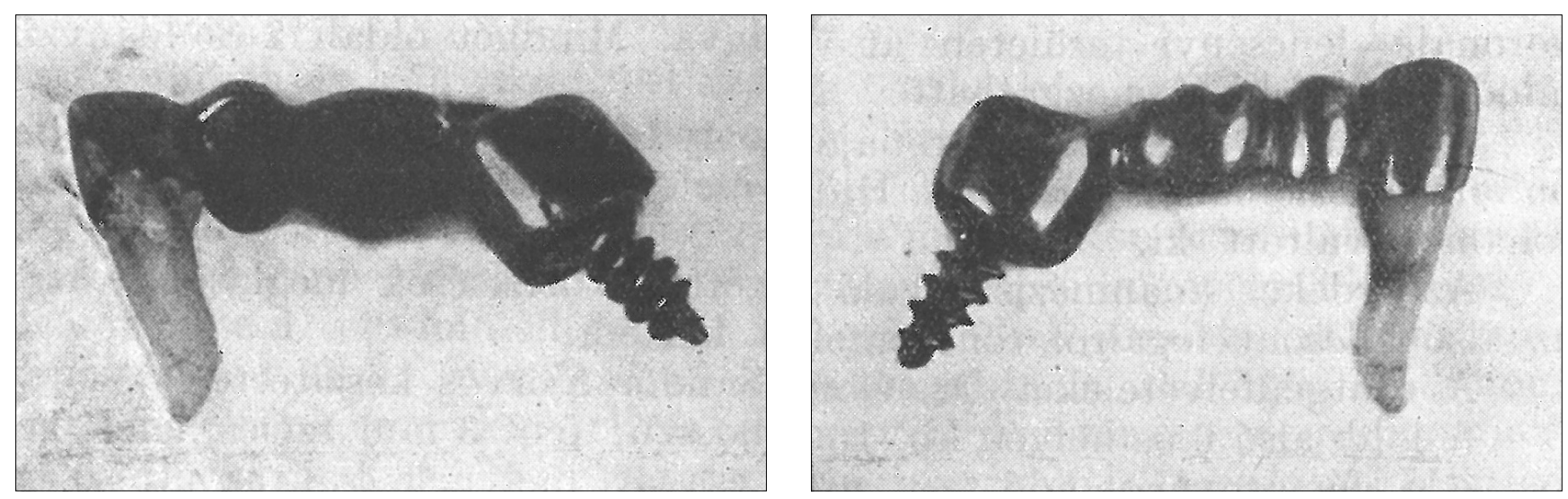

1. kép

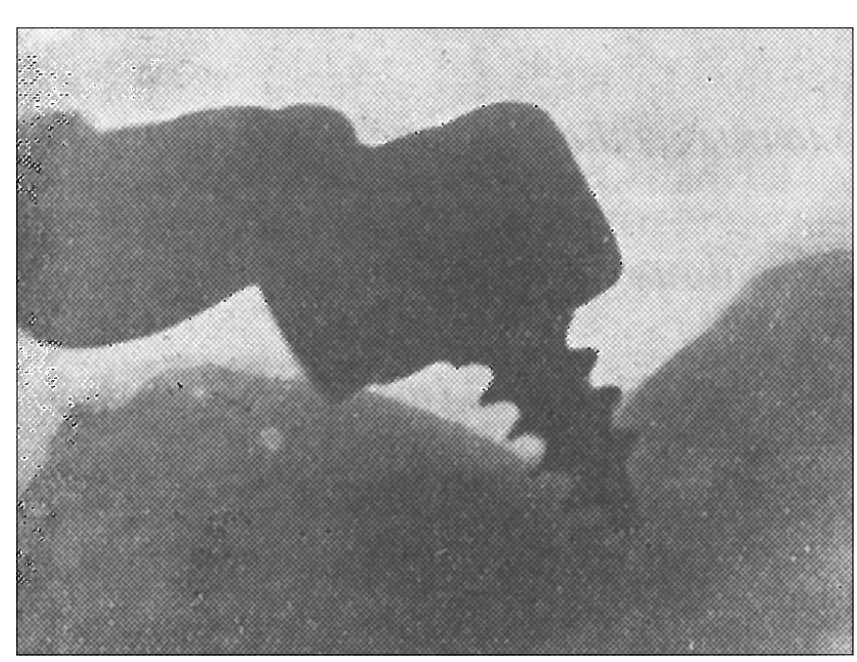

2. kép

Röntgenfelvételek készítése után és a betegvizsgálat során kiderítették, hogy a panaszt okozó 33-as fog pulpitises volt (a híd azon a fogon át volt rágva), melyet azután a koronán keresztül gyökérkezeltek. Mivel szilárdan állt a pillérfog és a csavar is, ezért továbbra is használni tudta a beteg azt a hídpótlását. A 43-46-os hidat azonban eltávolították (1. kép), mivel mindkét pillér (a csavar és a fog is) nagymértékben mobilis volt (a beteg elmondása szerint 2 éve mozgott, tehát ezt is kb. 22 évig használhatta). Felül a páciens fogatlan, az alsó 2-esek hiányoztak, az 1-esek kissé mozgathatóak voltak. A 46-os fog helyén lévő csavar felső 2/3-a körül csonttasak volt, kimozdulását elösegíthette, hogy 45-os szögben dőlt mesialis irányban (2. kép), míg az akkor is fixen álló 37-es fog helyén lévő csavar függőleges helyzetben állt (3. kép). A csavar implantátumok rozsdamentes acélból készültek, $10 \mathrm{~mm}$ volt a hosszuk és $3 \mathrm{~mm}$ az átmérőjük, a felső résztől lefelé elkeskenyedve. Az esetet Huszár György professzor is megemlítette - fényképpel - A magyar fogászat története címü munkájában [8]. Mivel nemzetközi fórumokon is hivatkoznak rá - mint az egyik legelső implantológiai

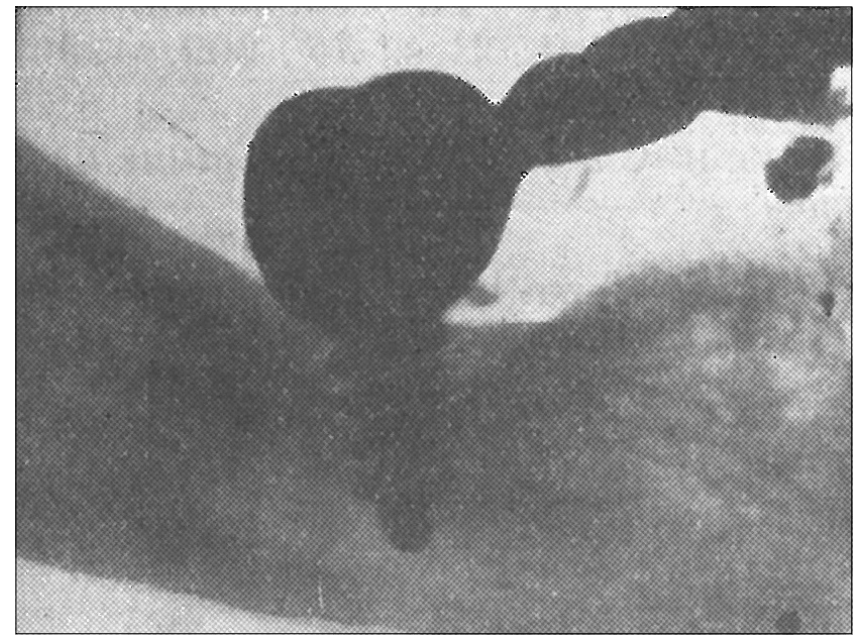

3. kép

próbálkozásra -, és debreceni vonatkozásai miatt is, igyekeztünk minél többet kideríteni a maguk idejében szenzációs beavatkozásokról. A korabeli újságok - 1934ben - részletesen foglalkoztak az új módszerrel, és kiderült, hogy szabadalmi eljárás is indult a különleges beavatkozás levédésére $[2,10,12,15]$.

\section{Mútéti körülmények}

Karácsonyi Ágoston debreceni fogorvos, aki 1933-ban végzett a $\mathrm{m}$. kir. Debreceni Tisza István Tudományegyetem orvosi karán, azzal az ötlettel kereste fel 1934-ben Hüttl Tivadar professzort (4. kép), a Sebészeti Klinika akkori igazgatóját, hogy alsó sorvégi foghiánynál idegen anyagból készült múgyökeret kellene behelyezni a páciensek állcsontjába, hogy ezáltal rögzített pótlást kaphassanak a betegek. Felső foghiánynál azért nem vetődött ez fel, mivel úgy vélték, hogy a szájpadlásos fogsor jobban rögzül és fixebben helyezkedik el a beteg szájában, mint az alsó protézis.

Hüttl professzor érdeklődését felkeltette a fogorvos 


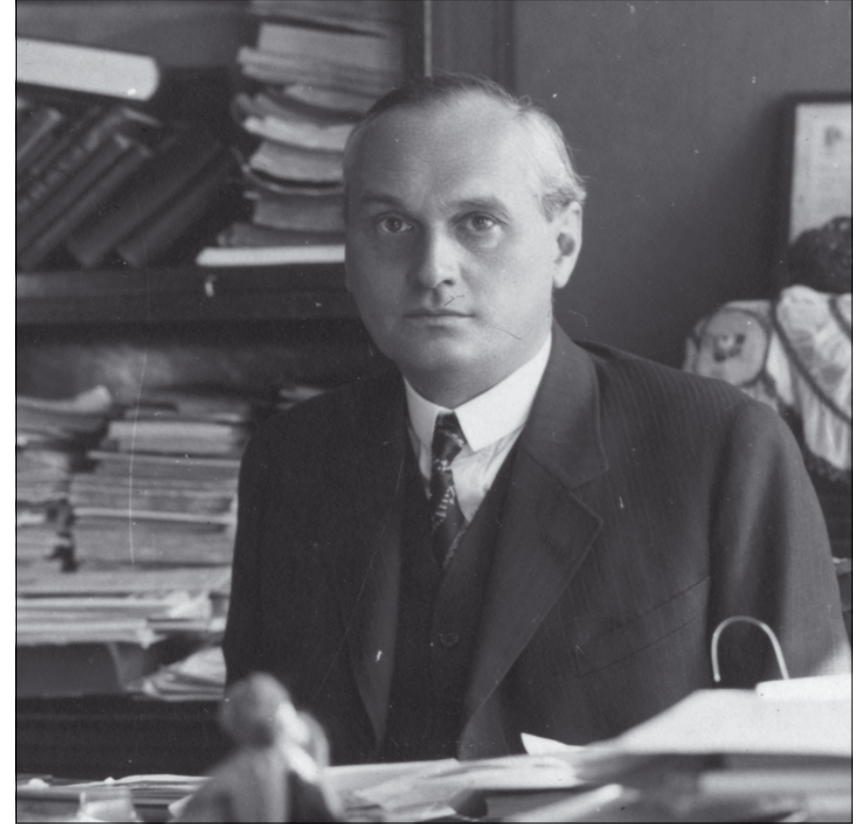

4. kép

kolléga elgondolása, és ő egyébként is támogatta a fogászati ellátást az egyetemen, hiszen elsőként létesített fogászati rendelést a klinikáján az 1930-as évek elején (melyből azután a Stomatologiai Poliklinika, majd Klinika nőtte ki magát). Átbeszélve a kérdéskört, először elefántcsont, vagy emberi csont pillér behelyezésén gondolkodtak, majd ezeket törékenységük miatt elvetették, végül rozsdamentes acélcsavar mellett döntöttek, és el is határozták a mielőbbi kezdést, arra az elhatározásra jutva, hogy „ne beszélgessünk, hanem kerítsünk beteget!”

A mútéteket felváltva végezte Hüttl professzor és Karácsonyi doktor. Először egy nő vállalkozott a beavatkozásra (az újságíró klub takarítónője), akinek az alsó állcsontjába jobb oldali hátsó müpillért csavartak be.

A mútét menete: vezetéses érzéstelenítés, metszés a nyálkahártyán, szétfejtették a csonthártyát, fúróval menetet fúrtak a csontba, a menetbe becsavarták a pillért (az acélcsavart), majd rtg.-kontroll következett. Naponta megvizsgálták a beteget, majd 6 nap (!) eltelte után a pillérre „illesztették” a hidat. A beavatkozás előtt szanálták a szájat (extrakciók, tömések elkészítése), és fontos azt is megemlíteni, hogy díjtalanul kapták a fogpótlást a betegek. Ezek után érthető, hogy jelentkezőkből nem volt hiány.

A takarítónő az újságíró klubban eldicsekedett - röntgenfelvételét mutogatva - a különleges pótlásával. Ezután nem csoda, hogy Hüttl professzor szándéka ellenére hamarosan országos szenzáció lett az új beavatkozásból. Ő ugyanis még várt volna a bejelentéssel, mivel először szakmai körökben szerette volna megvitatni az új eljárást, és azt is csak több eset után. Az 1934. szeptember 18-i újságcikkekben ismertetik, hogy kb. 8 hete kezdték a mútéteket, és addig már 7 mútétet végeztek, azokból egyet felső állcsontban. 3 be- teg kapott hídpótlást, de a költségek máris elérték az 500 pengőt! Szeptemberben még 18 müpillért szándékoztak behelyezni, majd egy-másfél évig vártak volna, hogy a pillérek stabilitását kövessék. Az eszközöket egyébként Szabó István orvosi műszerész ingyen készítette el [2, 10, 15].

Sajnos, többet nem tudhatunk meg a korabeli híradásokból a betegekkel és az esetszámmal kapcsolatban.

A következőkben ismertetjük, mi történt a - végezetül visszavonásra került - szabadalmi eljárás során.

\section{Szabadalmaztatás}

„Dr. Hüttl Tivadar orvos, egyetemi nyilvános rendes tanár és Dr. Karácsonyi Ágoston, orvos, fogszakorvos, debreceni lakosok, meghatalmazzák Kalmár J. és Kalmár L. mérnököket, hites szabadalmi ügyvivőket, Budapesten, hogy számukra és nevükben Magyarországra kizárólagos szabadalmat kérjenek és eszközöljenek ki a következö találmányra: Mú-pillérfog és eszköz annak az állkapocsban való megerősítésére”. A meghatalmazás 1934. szeptember 8-án készült Debrecenben [9.].

A meghatalmazott ügyvivők részletes leírással 1934. október 5-én nyújtották be a szabadalmi kérvényüket, melyhez a rajzokat - a későbbi feliratozás szerint - október 15-én pótolták [11].

A rajzok szerint háromféle eszközt akartak szabadalmaztatni (5. kép):

1. Műpillérfog négy különböző kiviteli alakkal (külön a metszők és a rágófogak helyettesítésére, más-más fejekkel). Anyaga rozsdamentes acél, csavarmenetes része van, fúróban végződik.

2. Eszköz (csavarhúzó, vagy csavarkulcs) „a pillérfog állkapocsba való becsavarására” (a vége lehet hajlított, vagy egyenes).

3. Fogószerű segédeszköz „a múpillérfog állkapocsba való becsavarása alatt a helyes helyzetben való tartására" (lehet egyenes, vagy könyök alakban hajított).

Hiányzik viszont a leírásból az újságcikkben említett előfúró, amely a beszámolók szerint menetes volt, és ezután csavarták be a múpillérfogat a csontba.

A tekintetes $\mathrm{m}$. kir. Szabadalmi Bíróság pecsétje szerint „Megtekintésre kitétetett 1935. március 1.”. Ezután azonban nem várt fordulat történt.

A beadványról tudomást szerzett Guttermuth János államilag vizsgázott fogász, aki a szabadalmi bejelentés ellen felszólalt, és képviselőjének Gárdos Andor hites szabadalmi ügyvivőt nevezte meg. A meghatalmazás 1935. április 20-án készült [5].

Ezután Guttermuth János nevében történt egy 6 oldalas felszólalás a m. kir. Szabadalmi Bíróság számára melyben kéri a „szabadalmat megtagadni és a bejelentőket egyetemlegesen P. 500- és még a felmerülö költségeim fizetésére kötelezni méltóztassék" [6].

Guttermuth részletesen kifejti, hogy az ő 1934. január 2-án nyomtatásban megjelent magyar szabadal- 
Fig.7 Fig.8 Fig.7 Fig.3 Fig.5
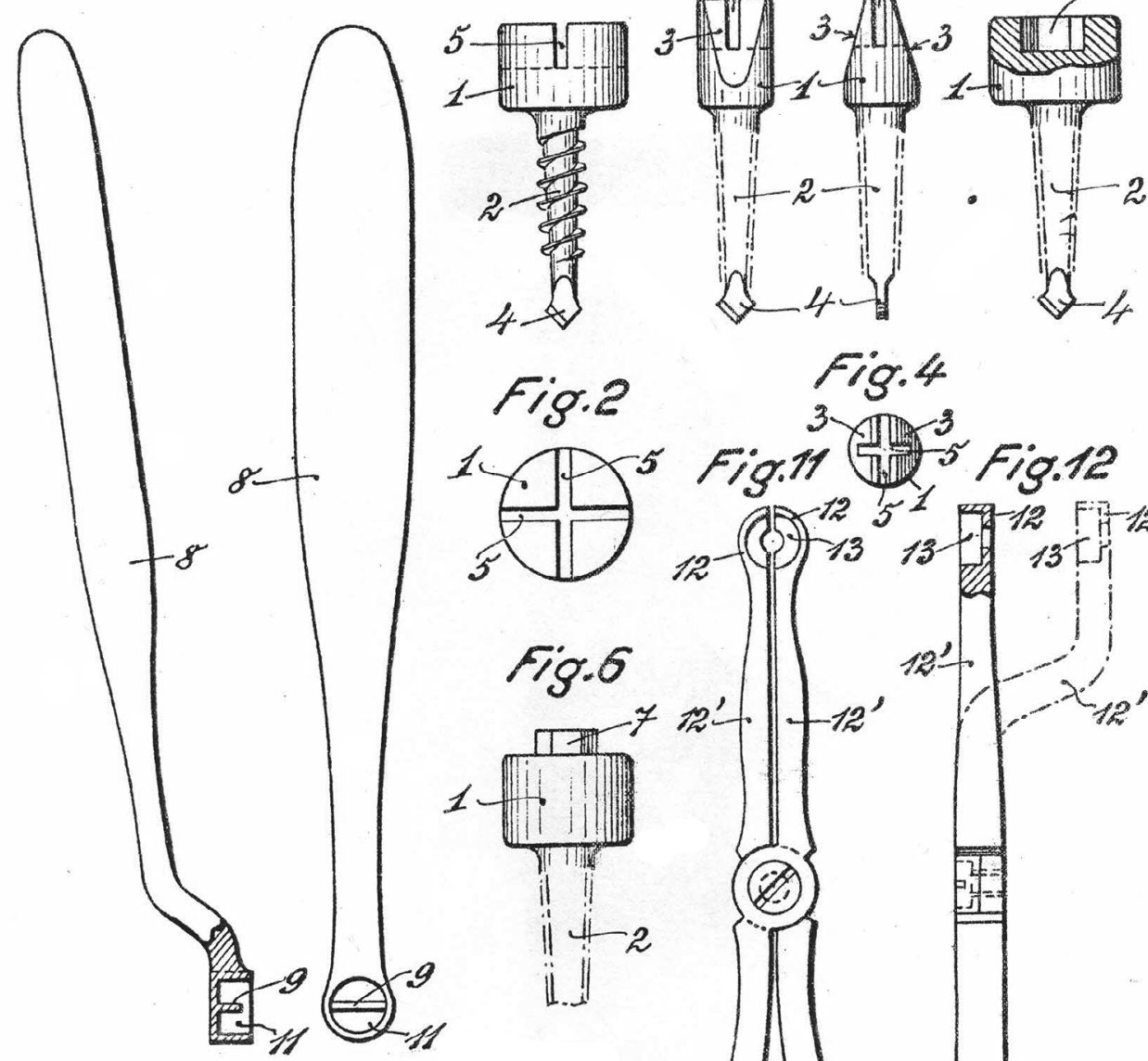

Fig.2 Fig.4

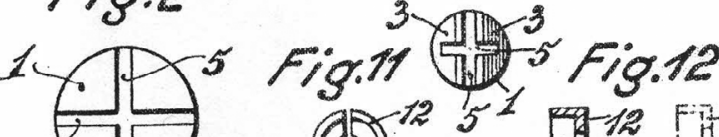

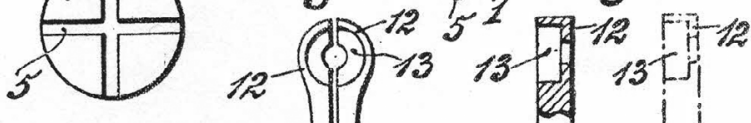

Fig. 6

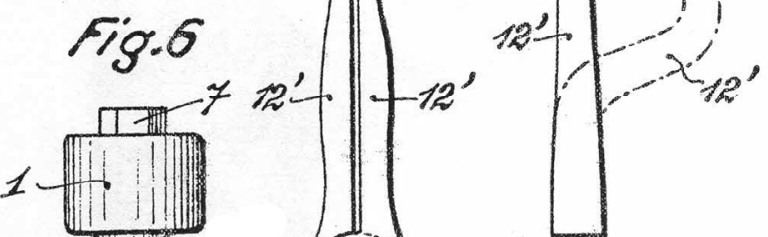

Fig.9

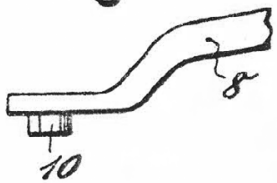

Fig.10
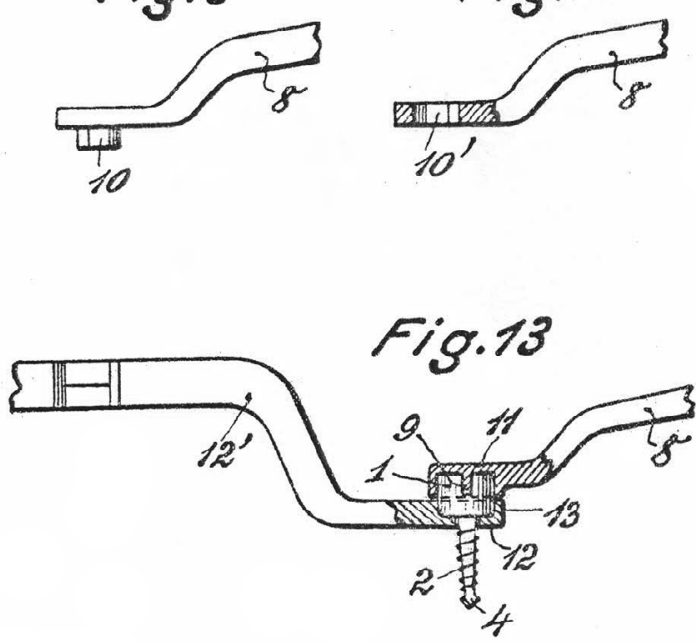

Fig.13 
ma [4, 6], és az 1932. június 10-én megjelent Ripperféle osztrák szabadalom [16] egymástól függetlenül, a „Hüttl-Karácsonyi által benyújtottat lerontják”. A felszólalás 1935. május 1-jén lett beadva a Szabadalmi Bíróságra [6].

Guttermuth János kifogásai, érvei a szabadalom ellen:

1. Szerinte a leírásból nem derül ki, hogy „külön a szerszámmal előfúrást végeznek-e, vagy minden előfúrás nélkül magát a múpillérfogat csavarják be a felnyitott ínyhúson keresztül az ép állkapocs-csontba."

2. A csavar behelyezése során - ha volt menetes előfúrás - csontdarabok törhetnek, szakadhatnak ki (,...a bejelentők a müködés sikeréhez szükséges fogásokat eltitkolták").

3. Ha nincs előfúrás, még inkább felmerül a csontdarabok letörése (amelyek komplikációkat okozhatnak).

4. A csavarfejek formáját több okból is kritizálja (a fejformák az iparban már ismertek).

5. A szabadalmi bejelentésben a behelyezés lépéseit, módját eltitkolták, míg az újságokban korábban megjelent riportokban részletes ismertetést adtak.

A felszólalásban leírja az igényeit, ezek: a szabadalom megtagadása, a bejelentők kötelezése 500 Pengő megfizetésére, valamint felmerülő költségei kifizetésére [6].

Egyébként Guttermuth János szabadalmáról elmondható, hogy eltér a Hüttl-Karácsonyi-féle beadványtól.

Címe: Múfogsor-rögzítés (A bejelentés napja 1932. július 21., a szabadalom megjelent 1934. január 2.) [18].

„Állkapocs-csontba alapcsavart, cső vagy fülescsavart" ültetett be. Az alapcsavar a foggyökeret pótolja. $\mathrm{Az}$ alapcsavar anyaga arany, ezüst, platina vagy rozsdamentes acél lehet. A müfog csavarmenetes csapját a furatba (alapcsavar) csavarják. Múfogsornál az alaplemez furatán áthatoló csavarokkal legalább két alapcsavarhoz rögzítenek. „Alapcsavarok célszerü elrendezése az elözápfogak helyei”. A fogsor ezáltal rögzítve lesz, vagy a beteg által eltávolítható és visszahelyezhetővé válik (tisztíthatóság) [4].

A Hüttl-Karácsonyi bejelentés visszavonása 1935 március 1. és május 1. között megtörtént, még Guttermuth János felszólalása előtt [19, 20].

A M. Kir. Szabadalmi Bíróság a bejelentőket (HüttlKarácsonyi) arra kötelezte, hogy a felszólalónak (Guttermuth J.) 50 Pengő felszólalási költséget fizessen [19].

\section{Konklúzió}

A leírtakból látható, hogy egy igen ígéretes módszer veszett el a szabadalom visszavonása miatt. Guttermuth szabadalma, bár kb. 2 évvel megelőzte hazánkban a Hüttl-Karácsonyi-eljárást, azonban más jellegú volt, és semmi adat nem lelhető fel betegben való alkalmazásáról. Sajnos, a Hüttl-Karácsonyi-módszer leírásánál is számos hiba figyelhető meg, például nem írták le részletesen a behelyezési eljárást - főleg az előfúrás vonatkozásában -, és a szabadalmi védettség kérésénél sem tettek említést az előfúró milyenségéről (anyaga, alakja, használata stb.).

A Harsághy doktor által említett beteg szájában megfigyelt 23 éves, illetve a még tovább is használt implantátum bizonyítja az eljárás gyakorlati sikerességét, és ezért igen sajnálatos, hogy feledésbe merült a módszerük. Az is kár, hogy Harsághy doktor a későbbiekben már nem tesz említést a beteg sorsáról (nem követte a beteget).

Egyébként valószínüsíthető, hogy a Harsághy doktor által ismertetett beteg nem pontosan emlékezett a behelyezés idejére (1936), mivel 1935 tavaszán $[19,20]$ már visszavonták a szabadalmat, és akkor biztosan leálltak a mútétekkel is, tehát a beteg hídjai régebbiek lehettek (1934 júliusa és 1935 márciusa között készülhettek).

Mindenesetre Hüttl Tivadar professzor és Karácsonyi Ágoston fogszakorvos nagy lépéssel járultak hozzá az implantológia kialakulásához. Próbálkozásuk - bár feledésbe merült - mindenképpen fontos mérföldkő volt, és kiemelendő, hogy kísérleteiket akkor végezték Debrecenben, amikor az orvosi karon még önálló Stomatologiai Klinika sem létezett.

További kutatásaink a többi implantációban részesült betegről fellelhető adatokra irányul.

\section{Irodalom}

1. Abraham CM: A brief historical perspective on dental implants, their surface coatings and treatments. The Open Dent J. 2014; 8: $50-55$.

2. Beszélgetés a kivehetetlen fogsor feltalálójával. Magyarország 1934. szeptember 21. 4.

3. GReEnfield EJ: Implantation of artifical crown and bridge abutments Dent Cosmos 1913; 55: 364-368.

4. Guttermuth J: Müfogsor rögzítés. Szabadalmi leírás (107925). 1934. január 2. M. Kir. Szabadalmi Bíróság, Országos Levéltár K szekció

5. Guttermuth J: Meghatalmazás. 1935. április 20. Országos Levéltár K szekció

6. Guttermuth J: Felszólalás Hüttl T. és Karácsonyi Á. szabadalmi ügyében. 1935. május 1. Országos Levéltár K szekció

7. HaRSÁGHy N: Az állkapocsba fémcsavarral rögzített híd. Fogorv Szle 1959; 52: 211-213.

8. HuszÁR Gy: A magyar fogászat története. Az Országos Orvostörténeti Könyvtár kiadványa, Budapest 1965; 195-196.

9. Hüttl T, Karácsonyı Á: Meghatalmazás. 1934. szeptember 8. Országos Levéltár K. szekció

10. Hüttl Tivadar egyetemi tanár nyilatkozata érdekes fogpótlástani kísérletekről. Az Est 1934. szeptember 18. 11.

11. HütTl T, KarÁcsony Á: Szabadalmi bejelentés. 1934. október 5. Országos Levéltár K szekció

12. Hüttl Professzor szabadalmaztatja az állkapocsba csavarható múfogat. Nemzeti Újság 1935. március 9. 9.

13. MARZIANI L: Subperiostale Gerüstimplantate zu protetischen Zwecken. Dtsch Zanhärzti Z 1955; 10: 1115-1120.

14. MitSCHERLICH: Die Replantation und die Transplantation der Zähne. Langenbeck s Archiv für klinische Chirurgie 1863; 4: 389-395.

15. Nagyjelentőségű fogpótlási kísérletek a debreceni Sebészeti Klinikán. Debrecen 1934. szeptember 18.

16. RIPPER E: Befestigung künstlicher Zähne in Kieferknochen. 15. Jänner 1932. Österreichisches patentamt. Patentschrift Nr. 128568. 
17. STROck AE: Experimental work on a method for the replecement of missing teeth by direct implantation of a metal support into the alveolus. Am J Orthod 1939; 25: 467-471.

18. Szabadalmi Közlöny 1933; 38: 45.
19. Szabadalmi Közlöny 1935; 40: 23.

20. Szabadalmi Közlöny 1935; 40: 56.

21. UlвRicht W: Historie de la medecine dentaire. Swiss Dent 1989; 10. (5) 7-23.

Kelentey B, Lukács L, Redl P, Hegedüs Cs

\section{Insertion of screw implant into the jaw in the 1930s at the Surgical Clinic in Debrecen}

The usage of dental implants in the last 30-40 years has significantly altered the potentials in the field of prosthetics. The first evidence of implantation comes from the Mayan culture (around $600 \mathrm{BC}$ ). In Europe various techniques and materials were used for implantation purposes between the 16th and 19th centuries. In Hungary it was in 1934 when the first screw implants were placed in the lower jaw, in Debrecen, which was almost immediately supplemented by a bridge restoration. The surgeries were performed by Tivadar Hüttl, professor of surgery and Ágoston Karácsony, dentist. The procedure was applied in several cases, for which they planned to submit a demand for patent protection. However, in the spring of 1935, their patent claim was withdrawn due to a pleading of a licensed dentist in Budapest.

We do not know the exact number of inserted implants, or the rate of success, however, their durability is supported by the fact, that there was a patient treated in 1959, who still used such fixed prosthesis. Based on the above case a scientific article was published with photographs and x-rays. Our article briefly reviews the process, its tools, and the controversies surrounding the patenting.

Keywords: implant, screw implant. 